\title{
Trends in Workers' Remittances : A Worldwide Overview
}

\section{BILIN NEYAPTI}

To cite this article: BILIN NEYAPTI (2004) Trends in Workers' Remittances : A Worldwide Overview, Emerging Markets Finance and Trade, 40:2, 83-90

To link to this article: https://doi.org/10.1080/1540496X.2004.11052567

Published online: 07 Dec 2014.

Submit your article to this journal $\square$

山 Article views: 16

4 Citing articles: 1 View citing articles $\square$ 
Emerging Markets Finance and Trade, vol. 40, no. 2,

March-April 2004, pp. 83-90.

(C) 2004 M.E. Sharpe, Inc. All rights reserved.

ISSN 1540-496X/2004 \$9.50+0.00.

\title{
BILIN NEYAPTI
}

\section{Trends in Workers' Remittances}

\author{
A Worldwide Overview
}

\begin{abstract}
Increasing economic integration around the world bestows workers' remittances a growing potential importance as a source of financing foreign transactions. This paper investigates trends in workers' remittances in developed and less developed countries since the 1980s. Both the magnitude of workers' remittance flows, in comparison to some other major aggregates, such as gross domestic product and foreign direct investment flows, and the relative stability of workers' remittances reveal that policies to attract workers' remittances bear great importance for especially less developed economies.
\end{abstract}

Key words: financing current account, worker remittances.

One aspect of global economic integration is the potentially increasing importance of workers' remittance flows. Indeed, the annual Global Development Finance report of the World Bank (2003) has devoted a whole chapter on the worker remittance flows. ${ }^{1}$ Although workers' remittances (WR) are reported under the current account in the balance of payments statistics, they could easily be considered as a financing item. In addition to their role as a source of financing the current account, however, WR flows have potentially important economic effects connected with the motives of either consumption smoothing or investment in the country of origin (see, for example, Lucas and Stark 1985; Poirine 1997). That official WR in some countries amount to more than 20 percent of their gross domestic product $(\mathrm{GDP})^{2}$ demonstrates the potential importance of WR in those countries.

Bilin Neyapti (neyapti@bilkent.edu.tr) is an assistant professor at Bilkent University, Department of Economics, Ankara, Turkey. The author thanks an anonymous referee for useful comments. Any errors are solely the responsibility of the author. 
This paper provides an overview of global trends in the magnitude and concentration of WR since 1980. Notwithstanding the potentially important roles of WR flows, since a major part of WR are transferred via unofficial channels, ${ }^{3}$ measuring their magnitude as well as analyzing their full impact on the economy is rather difficult. Possibly due to this constraint, related empirical literature has concentrated on the determinants of, if only official, WR, rather than their effect on the economy. Nevertheless, considering that WR are, generally speaking, by far a greater source of income in less developed countries than in developed economies, it is possible to argue that the downward bias in the WR figures is a uniform problem in countries where they have a possibly significant impact. Hence, comparative evidence provided in this study provides useful information regarding the potential importance of WR flows on macroeconomic outcomes and thus has important policy implications.

In order to assess the scale of importance of WR flows to the developed and less developed counties, we report their magnitude in relation to both foreign direct investment (FDI) and the size of the economy. In addition, we report a measure of stability of WR flows in comparison to that of FDI.

Our investigation reveals that both the aggregate and per country flow of WR are much higher to less developed countries than to the developed countries. However, WR flows show much smaller variation over time than FDI in developed countries. Whereas the instability in the WR flows to less developed countries slightly declined in the 1990s, it remains much higher than in the developed countries since the 1980s. These observations draw attention to the potentially important role of WR flows for especially less developed countries, and thus call for appropriate policy actions to attract and stabilize them.

\section{Workers' Remittance Flows in Numbers}

This analysis covers the period from 1980 to 1999, and more than 100 countries, of which sixteen are developed countries. We first summarize the magnitude of the aggregate WR flows across the world, and then report the average trends in both less developed and developed countries with regard to the relative magnitudes of WR to major relevant macroeconomic aggregates (see the next subsection). We then report some observations on the rankings of countries with respect to the shares of WR flows in various other relevant macroeconomic variables (see "Country-Based Comparisons of WR Flows" subsection).

\section{Trends in Aggregate and Average Flows of Workers' Remittances to}

\section{Developed and Less Developed Countries}

Table 1 shows the aggregate WR flows to the groups of developed countries and less developed countries, in ratio to the aggregate GDP and FDI flows of the respective groups. As the sample covered changes based on data availability across 
Table 1

“Aggregate” Workers' Remittance Receipts in GDP to FDI Ratios

\begin{tabular}{cccccc} 
& \multicolumn{2}{c}{ GDP } & & \multicolumn{2}{c}{ FDI } \\
\cline { 2 - 3 } \cline { 5 - 6 } & $1980 s$ & $1990 s$ & & $1980 s$ & $1990 s$ \\
\hline Developed & 0.10 & 0.11 & & 15.9 & 8.5 \\
$\quad$ countries & $(16)$ & $(16)$ & & $(16)$ & $(16)$ \\
Less developed & 0.85 & 0.91 & & 151.3 & 59.9 \\
countries & $(110)$ & $(125)$ & & $(104)$ & $(117)$
\end{tabular}

Note: Figures in parentheses are the numbers of countries from which the average is obtained.

the variables and time period covered, we use the same country-time observations for both the numerator and the denominator in calculating each ratio reported in the table, in order to give as unbiased an account for the aggregate trends in WR as possible. ${ }^{4}$

Table 1 indicates that the ratio of aggregate WR flows to aggregate GDP in less developed countries, which is close to 1 percent, is notably much higher than that of the group of developed countries. On the other hand, we observe that the average ratio of WR to FDI has fallen over the two decades within the groups of both developed and less developed countries. However, whereas WR flows to less developed countries were more than the total FDI flows to these countries in the 1980s, in the 1990s, the WR flows still constituted an impressively high portion of FDI flows in less developed countries.

In view of Table 2, which demonstrates that FDI to less developed countries has increased more than sixfold during the past two decades, on the aggregate, the potentially important role of WR in these economies obviously remains. Indeed, WR flows to the group of less developed countries have about doubled since the 1980s. For the group of developed countries, whereas WR receipts have increased on the aggregate during the past two decades, its ratio to FDI has almost been halved, as the FDI flows to developed countries have also more than doubled. Thus, it is possible to say that the relative importance of WR in financing current account has decreased in this group of countries. Interestingly, however, FDI to GDP ratios in groups of developed and less developed countries have been, on the aggregate, very similar to each other in both decades. ${ }^{5}$

We next view the trends in country averages of WR in terms of its ratios to some relevant macroeconomic indicators within the groups of less developed and developed countries. Table 3 indicates that there is only a slight increase in the ratio of WR to GDP in less developed countries, on the average, coupled with a slight 


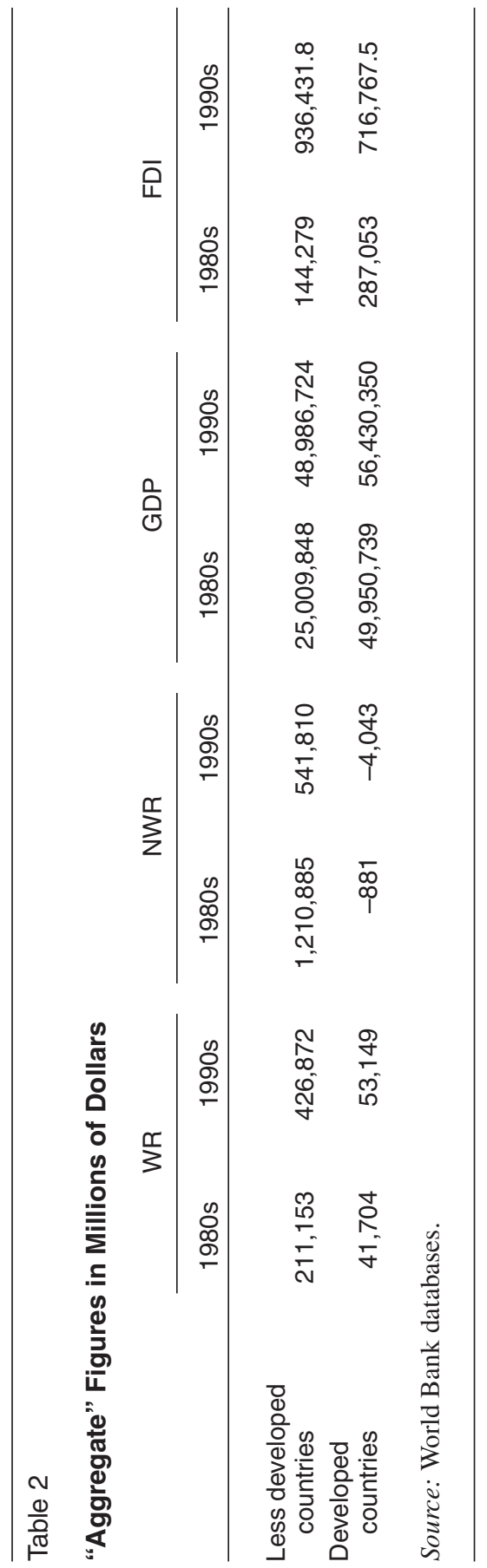


Table 3

Average Ratio of WR Receipts in GDP to FDI Ratios

\begin{tabular}{lccccc} 
& \multicolumn{2}{c}{ GDP } & & \multicolumn{2}{c}{ FDI } \\
\cline { 2 - 3 } \cline { 5 - 6 } & $1980 s$ & $1990 \mathrm{~s}$ & & $1980 \mathrm{~s}$ & $1990 \mathrm{~s}$ \\
\hline Developed & 0.18 & 0.15 & & 20.6 & 1.72 \\
$\quad$ countries & $(16)$ & $(16)$ & & $(16)$ & $(16)$ \\
Less developed & 2.25 & 2.57 & & $2,546.3$ & 906.2 \\
$\quad$ countries & $(110)$ & $(125)$ & & $(104)$ & $(117)$
\end{tabular}

Note: Figures in parentheses are the numbers of countries data is based on.

decrease in the same ratio in the group of developed countries, on average. On the other hand, we observe that the average ratio of WR to FDI has fallen over the two decades for both developed and less developed countries. Considering the increase in the aggregate FDI flows to the group of less developed countries, however, this observation indicates that FDI started to flow to those countries that do not most heavily receive the WR.

Inspecting net workers' remittance receipts (NWR) reveals a similar picture as the one discussed above. The differences observed with regard to NWR can nevertheless be listed as follows: ${ }^{6}$ NWR flows in the group of developed countries are on average, negative, with less than 0.1 percent of GDP, whereas those in less developed countries are about (positive) 1 percent of GDP, on average. On the aggregate (see Table 2), NWR was positive in the group of less developed countries both during the 1980s and the 1990s, though it was about half during the 1990s, as compared to the 1980s. In the group of developed countries, on the other hand, NWR was negative in both decades and increased about 4.5 times in the 1990 s, as compared to the 1980s.

\section{Country-Based Comparisons of WR Flows}

Besides the aggregate ratios and averages across time and country in the groups of developed and less developed countries, we also look at the rankings of individual countries with respect to their ratio of WR to various macroeconomic aggregates of interest. The following summarizes the main observations obtained for the decade of the 1990s.

Among the group of developed countries, Spain receives, by far, the largest share of WR in ratio to GDP: ${ }^{7} 0.45$ percent. In terms of the share of WR in FDI, Austria ranks at the top (by 65 percent), followed by Japan and Spain in the case of the share of FDI. In terms of the share of WR in portfolio inflows, Spain ranks at 
the top again, with 18.5 percent, followed with Austria, with 10.2 percent. During the 1990s, Austria and Spain also rank among the highest with respect to the ratio of NWR to FDI and GDP. We also observe that Japan, the Netherlands, France, Norway, the United States, Belgium, Germany, and Switzerland have all been net remittance providers.

For the group of less developed countries, Lebanon ranked at the top of the list for the ratio of WR to GDP, with 38.8 percent during the 1990s, followed by Samoa, Eritrea, and Yemen Republic, all with ratios larger than 20 percent of GDP. Jordan, Cape Verde, Tonga, Albania, and El Salvador ranked next, with WR flows more than 10 percent of their respective GDPs. Among the other countries that receive WR flows that are more than 5 percent of GDP, we observe Morocco, Egypt, and Sri Lanka. Portugal, Tunisia, Pakistan, Greece, Turkey, and India all receive WRs that range between 1 and 5 percent of their respective GDP.

When WR flows, as a financing item, are viewed in ratio to FDI, we observe that the majority of less developed countries receive a very significant flow of WR with respect to FDI inflows. Among the group of less developed countries, fourteen countries, including India, receive WR more than tenfold of their net FDI flows; twenty-one countries, including Egypt, Turkey, Pakistan, Portugal, and Greece, receive WRs of more than twice their net FDI flows.

\section{How Stable Are WR Flows as Compared to FDI?}

In this section, we compare stability of WR receipts to that of FDI in order to assess the reliability of the former vis-à-vis the latter in the two country groups, on average. Comparing the stability of WR to that of FDI is especially important, since FDI is supposed to be the most resilient component of the balance of payments due to its relatively long-term nature. ${ }^{8}$ We measure stability as the average coefficient of variation ${ }^{9}$ in the respective flows over the periods of the 1980s and 1990s in the groups of developed and less developed countries.

Table 4 demonstrates that WR flows are far more stable than FDI flows in the group of developed countries during both decades, where the difference is significant at the 1 percent level..$^{10}$ However, this is not the case in the less developed countries: the variability in WR and FDI is not statistically different from each other during either the 1980s or the 1990s. In addition, we observe that while no statistically significant change is observed with regard to the variability of the FDI flows to the less developed countries between the two decades, the instability of FDI flows in the group of developed countries has significantly increased, while that in the group of developed countries has increased during the 1990s as compared to the 1980s. On the contrary, the instability in WR flows declined within the group of less developed countries during the 1990s (though significant at only the 10 percent level), while it remained similar to before in the group of developed countries.

It is also possible to observe that, during both decades, differences between the variability of WR are much higher (significant at the 1 percent level) in the group 
Table 4

Average Coefficient of Variation of WR and FDI

\begin{tabular}{|c|c|c|c|c|c|c|}
\hline & \multicolumn{2}{|c|}{ WR } & \multicolumn{4}{|c|}{ FDI } \\
\hline & 1980s & 1990s & $1980 s^{1}$ & $1990 s^{1}$ & $1980 \mathrm{~s}$ & 1990s \\
\hline $\begin{array}{l}\text { Developed } \\
\text { countries }\end{array}$ & $\begin{array}{l}37.3 \\
(9)\end{array}$ & $\begin{array}{l}39.4 \\
(10)\end{array}$ & $\begin{array}{l}84.8 \\
(9)\end{array}$ & $\begin{array}{l}93.2 \\
(10)\end{array}$ & $\begin{array}{l}92.2 \\
(16)\end{array}$ & $\begin{array}{l}83.0 \\
(12)\end{array}$ \\
\hline $\begin{array}{l}\text { Less } \\
\text { developed } \\
\text { countries }\end{array}$ & $\begin{array}{l}69.5 \\
(66)\end{array}$ & $\begin{array}{l}53.2 \\
(89)\end{array}$ & $\begin{array}{l}86.9 \\
(66)\end{array}$ & $\begin{array}{l}54.9 \\
(89)\end{array}$ & $\begin{array}{l}73.8 \\
(106)\end{array}$ & $\begin{array}{l}161.8 \\
(124)\end{array}$ \\
\hline
\end{tabular}

Notes: Figures in parentheses are the numbers of countries, on the basis of which the average is obtained (the data are different from those reported in Table 3 due to zero reported WR flows in various countries). ${ }^{1}$ For comparison, numbers are obtained based on the same sample as that of WR.

of less developed countries than in the group of developed countries. This difference, however, is not significant with respect to the variability of FDI in the respective groups.

The larger samples for the FDI figures in the 1990s, as compared to the 1980s (the last two columns of Table 4), were mainly due to the inclusion of the data from the formerly socially planned economies. However, test results including these countries do not differ much from those using the comparable samples.

As a result, the figures indicate that WR flows are a more reliable source of foreign exchange than FDI in the developed countries, but not in the less developed countries. This is possibly indicative of the lack of stability and policies to attract WR in the less developed countries. Although the variability of WR flows to less developed countries declined during the 1990s, they remained more volatile than in the developed countries throughout the 1980s and 1990s.

\section{Conclusions}

The analysis in this paper reveals that workers' remittances flows have been, both on the aggregate and in per country terms, notably larger in less developed countries than those in developed countries. Moreover, WR flows to individual countries have been more stable, on average, than FDI flows in developed countries. However, WR flows have been less stable in less developed countries than in developed countries since the 1980s.

In view of increasing global economic integration, the evidence in this paper indicates that policies to attract workers' remittances, possibly sound exchange rate policies and institutional and structural efforts to achieve macroeconomic and 
political stability, are of utmost importance for less developed countries. ${ }^{11}$ Indeed, it is also argued that better governance, more developed financial systems, and more openness that attracted workers' remittances would also increase the FDI flows. ${ }^{12}$

\section{Notes}

1. The World Bank analysis is confined to data starting in the late 1990s.

2. Specifically, in Lebanon, Samoa, Eritrea, and Yemen.

3. See, for example, McCormick and Wabha (2000), Russell (1986), Rodriguez (1996), and Swamy (1981).

4. Due to the large sample coverage, the ratios are fairly informative about the world trends despite the missing observations.

5. In the 1980s, the FDI/GDP ratio was about 0.6 percent in both country groups and about 1.9 percent for the less developed countries and about 1.3 percent in developed countries during the 1990s.

6. Figures are not reported, but are available upon request from the author.

7. The ranking of countries with respect to the ratios of WR to both GDP and FDI is available upon request from the author.

8. See, for example, World Bank (2003).

9. Coefficient of variation (CV) is calculated as: [(standard deviation/average)*100] per country over the 1980s and 1990s. The reported numbers are the averages of CV across countries.

10. $t$-tests are performed both using the same sample for both variables and using the different samples, reported in Table 4. Test results are available upon request from the author.

11. Aydas et al. (2003) observe, for example, that these variables significantly affect WR flows in Turkey.

12. See World Bank (2003).

\section{References}

Aydas, O.T.; B. Neyapti; and K. Metin-Ozcan. 2003. "Determinants of Workers Remittances: The Case of Turkey." Bilkent University, Ankara.

Lucas, R.E.B., and O. Stark. 1985. "Motivations to Remit: Evidence from Botswana.” Journal of Political Economy, 93, no. 51: 901-918.

McCormick, B., and J. Wabha. 2000. "Overseas Employment and Remittances to a Dual Economy.” Economic Journal, 110, no. 463: 509-534.

Poirine, B. 1997. "A Theory of Remittances as an Implicit Family Loan Agreement.” World Development 25, no. 4: 589-611.

Rodriguez, E.G. 1996. "International Migrant's Remittances in the Philippines." Canadian Journal of Economics 29, special issue part 2: S427-S432.

Russell, S.S. 1986. "Remittances from International Migration." World Development 14, no. 6: 677-696.

Swamy, G. 1981. "International Migrant Worker's Remittances: Issues and Prospects." Working Paper No. 481, World Bank, Washington, DC.

World Bank. 2003. "Global Development Finance.” Washington, DC. 